\title{
Buying vs. Leasing Equipment: Which One is Better?
}

\section{Rumzz Bajwa (SMB Compass)}

\section{KEYWORDS: Leasing Equipment, Equipment loan.}

When running a business, you might have come across the same question as everybody else, "should I buy or lease equipment?" The answer to that question primarily depends on your business' needs.

For instance, if you need an equipment upgrade every year or two, you might benefit more from leasing. Buying makes much more sense for equipment with longer usable life. Typically, those in the medical industry might benefit more from leasing, while construction businesses might want to consider buying equipment upfront.

This article will look at both options and discuss some tax benefits with equipment leasing (https://www.smbcompass.com/loanprogram/equipment-financing/) and buying.

Let's start.

\section{Equipment Leasing Advantages}

From a financial standpoint, equipment leasing can be a more attractive choice. It's the easiest way to obtain much-needed equipment without putting a strain on your company's capital.

Here are four more advantages of renting equipment:

\section{Upgrade anytime}

With equipment financing, you won't have to worry about your equipment getting obsolete. Since you're only renting it, you'll get to return the equipment after the lease period. It allows you to switch it up with a newer, more advanced tool.

\section{Less initial cost}

As mentioned, if your company is on a cash crunch and can't afford to buy new equipment, leasing can be a much better choice. Equipment leasing doesn't require business owners to shell out a significant amount of cash. Equipment leasing companies also rarely require a down payment from their clients. It's a more sensible way to obtain vital equipment without significantly affecting your business' cash flow.

\section{Easier to obtain}

Leases are generally much easier to process than equipment loans which are sometimes necessary to buy business equipment. The approval for equipment leasing won't generally rely on your credit or financial background. So, even if you have bad credit, you'll still be able to obtain business equipment.

\section{Equipment Leasing Downsides}

Here are the disadvantages of leasing that you should take into account when considering this option:

\section{You won't own the equipment}

With leasing, you'll have to return the equipment after the lease period has expired. You won't be able to include it on your company's list of assets, and therefore, can't be used as collateral when applying for a loan since you don't own the equipment in the first place. You can't build equity on it, and there won't be a chance to earn your money back.

\section{Higher overall costs}

In the long run, leasing equipment could end up being more expensive than buying. For instance, tower cranes have a purchase price of $\$ 300,000$ to $\$ 1,500,000$. Renting one costs around $\$ 15,000$ per month. If your lease period is two and a half years, you could end up paying $\$ 5,400,000$ by the end of the lease period. This amount is significantly higher than the buying price of the crane itself.

\section{Buying Equipment Advantages}

Among the many reasons why businesses prefer buying equipment is that they get to take full ownership of it in the end. Here are the advantages of buying equipment:

\section{Lower overall cost}

As mentioned above, leasing equipment may be more expensive than buying in the long run. In equipment leasing, you could end up paying twice the original price 
of the equipment, whereas buying lets you save that money.

\section{Full ownership of the equipment}

Unlike leasing, buying equipment allows you to take full ownership of the equipment after making repayments for the equipment loan. This option allows you to declare the equipment as part of your company's assets, thus diversifying your asset portfolio. In turn, your chance of getting approved for a more comprehensive loan in the future increases.

\section{Wide range of equipment choices}

With leasing, you'll only get to rent a specific make and model. However, if you buy the equipment, you'll have different choices. You could opt for the latest version or choose one with better functionalities. If you opt to buy, you get to choose the best equipment that you think would contribute best to your company's bottom line.

\section{Buying Equipment Downsides}

There are also potential downsides to buying equipment, including:

\section{Higher upfront cost}

While you may incur lower overall costs if you buy equipment, if you decide to buy the equipment outright, you'd have to shell out a much higher upfront cost. For businesses experiencing cash flow issues, this could pose as a threat. If they fail to manage it, they could end up losing control of their finances.

\section{You'll have to factor in your maintenance costs}

Buying equipment means that you'll ultimately be responsible for it. In other words, you'd have to shoulder all the costs associated with it, including the maintenance and repair costs. You could do a rough estimate of the expenses depending on the type of equipment you have. However, at the very least, these costs could add up to hundreds to thousands of dollars.

\section{Higher chances of the equipment getting obsolete}

Machines and equipment get outdated as manufacturers discover ways to improve their functionality. When you buy any equipment, you'll also risk getting stuck with an outdated device. Unlike equipment leasing, where you can return the equipment after the end of the lease period, purchasing your equipment doesn't offer the same benefit.

With that, you want to make sure that the tool you'll buy will be worth your investment. If you think that it has lesser chances of being outdated fast, it might be worth considering. However, if you think you'll need to replace your equipment regularly to maintain a competitive edge and stay up-to-date with the changes, leasing might be a better choice.

\section{Tax Benefits with Equipment Leasing and Buying}

The good news is that both leasing and buying equipment entitles you to a tax break. As long as you declare that the equipment or machinery is $100 \%$ for business use, the Internal Revenue Service (IRS) may allow you to get a tax deduction for it.

With equipment leasing, the rental payments the business makes every month can be written off as deductions. However, it's also worth noting that if the equipment is listed as a rent-to-own type or under a conditional sale, the IRS could deny rental costs as tax deductions.

Similarly, buying a piece of equipment also subjects the business to a hefty tax deduction. According to Section 179 of the Tax Deduction, business owners can deduct the full price of specific business equipment in their taxable income on the same tax year that the equipment was bought.

\section{The Bottom Line: Should You Buy or Rent Equipment?}

Deciding whether to go with leasing or buying equipment for your company will depend mostly on your company's budget and needs. If you can afford the high upfront costs of equipment and don't mind the risk of becoming obsolete after a few years, buying might be a viable choice. However, if you prefer to pay monthly rents instead of producing shelling out a significant amount, leasing would make more sense.

However, before going on to something, be sure to learn about its pros and cons. It's worth noting that the decision you'll make will affect the bottom line of the business. The more you know, the better informed you will be when making a decision. 
